\title{
CURRENT IMAGE OF CHINA
}

\section{THOMAS CHIANG BLAIR ${ }^{1}$, CHIA-CHUN LIN ${ }^{2}$, WEI-CHEN YANG ${ }^{3} \&$ YA-CHIEH, LEE $^{4}$}

${ }^{1}$ Assistant Professor, Department of Creative Product Design, Asia University, Taiwan R.O.C

${ }^{2}$ Assistant Professor, Department of Visual Communication Design, Southern

Taiwan University of Science and Technology, Taiwan R.O.C

${ }^{3}$ Assistant Professor, Department of International Business, Southern Taiwan

University of Science and Technology, Taiwan R.O.C

${ }^{4}$ Assistant Professor, College of Culture and Creativity, Shih Chien University, Taiwan R.O.C

\begin{abstract}
The general assumption about the perception of a nation is any attribute that can associate with a country, which affects nation's identity, image and reputation. The only problem is that there are no clear definitions what it is or what attributes actually make up of it. Therefore, it is difficult to find an adequate theory and model that would reflect comprehensiveness of this subject. Hence, due to the lack of awareness on the subject, it raises many questions such as what is national image. What parts of the nation is being branded? Is it possible to branding a nation? What are the tools and measurements needed for national image? Does a nation actually need branding? What effect of branding has on a nation? etc.

In order to achieve our purposes, the research used brand China as an example; research intended to explore the current perceived image of China and to identify the "gap" between its image and its reality. With this advanced research on the subject, we can possess better methods and understanding, and it could be beneficial for countries in their future development.

KEYWORDS: Nation Branding, Nation Identity, Nation Image \& Nation Reputation
\end{abstract}

Received: May 02, 2017; Accepted: May 23, 2017; Published: Jul 01, 2017; Paper Id.: IJCMSAUG20171

\section{INTRODUCTION}

In this competitive world of today, each nation has to compete with others for having its share of the world's wealth, talent, and attention. However, national image branding cannot be achieved just only by governing a nation in a traditional way anymore. Nowadays, nations need to promote themselves in a way that can get the attention of people and attract tourism, investment, mega-events, etc. Therefore, a proper branding of a nation is very vital in creating a positive national brand image and reputations for the nation's competitive edge.

Thus, national image branding is a relatively new term and new emerging theories; nevertheless, it is not a new concept. Nations had always been branded themselves through their mythology, anthems, symbols, currency, and names. However, many nations and government experts are still unfamiliar with its concept and how it really works. Hence, due to the lack of awareness on the subject, it raises many questions such as what is national image branding. What parts of the nation is being branded? Is it possible to branding a nation? What are the tools and measurement need for national image branding? Does a nation actually need branding? What effect branding has on a nation etc.? 
Hence, national image branding involved in many aspects of the nations' character such as environment, people, tourism, business, governance, politics, etc. (Fan, 2006). Thus, according to Anholt (2005:22) "branding (a nation) is the process of designing, planning and communicating the name and the identity, in order to build or manage the reputation of a country." Nevertheless, to many nations the key problem is not why or should, but how to brand nation itself? Therefore, on this research, the author attempts to identify the relevant factors underlying the development of national image branding and to develop a definition and working model to assess the association among those factors.

\section{Research Background}

National image branding is a potentially powerful solution that can provide nations with economic, social, and cultural benefits. It had emerged as a modern-day phenomenon, as many nations have now turned to brand management techniques in order to compete effectively on the world stage (Dinnie, 2008). National image branding is concerned with the planning, governance, or economic development of the nation (Anholt, 2008) and combines both theory and practices that deal with the entire nation rather than any single commercial product or service.

Thus, according to the past researches, national image branding for many of us is just like any commercial or product branding, because nations can also be packaged, repackaged, position, repositioned and communicated in various ways just like commercial or product brand, which is why, it often fell into the field of marketing. Therefore, national image branding in this research can be viewed as developing national marketing strategies (McCarthy and Norris, 1999). It could help a nation, not just improve its identities and image, but also can improve its overall reputation in the world. However, the biggest challenge for many nations is how to communicate one single consistent image to different audiences in different parts of the world.

\section{Research Objective}

The general assumption about the national image branding is any attribute that can associate with a country, which affects nation's brand identity, image and reputation. However, the only problem is, there is no clear definition what it is or what attributes actually make up of it. Therefore, it is difficult to find an adequate theory and model that would reflect comprehensive on this subject.

So, in order to achieve our purpose, the research uses brand China as an example; research intended to explore the current perceived image of China and to identify the "gap" between its image and its reality. Hence, to understand China's consumer culture is a good starting point for understanding the nation itself, as it races toward superpower status. Though the country's economy and society are evolving rapidly, the underlying cultural blueprint has remained more or less constant for thousands of years. China is a Confucian society, a quixotic combination of top-down patriarchy and bottomup social mobility.

Their search examines the origins and interpretations of the concept national image branding and also the process of product branding and commercial branding. Hence, with the advanced research on the subject, nations can possess better methods and understanding of national image branding, it could be beneficial to many countries in the future for economic development and use. To achieve the objectives, the research formulates the following research questions:

- How does brand China's government and its peoples effective nation's identity, image, and reputation?

- How strong is the brand China's product position relative to its nation's overall image? 


\section{LITERATURE REVIEW}

On this research the author argues, the nation is a conceptual territorial construct of a country, although often the time people used interchangeably, nevertheless they're different. Hence, the idea of a nation is not necessarily bound to geographic locations (Kotler, quoted in Frost, 2004), it is not only more precise but more flexible a concept than country and is better suited to global concepts of the market. Nation conveys a set of meanings that are both historical and contemporary (O'Shaughnessy and O'Shaughnessy, 2000). A country on the other hand is what the people of a country share similar values, beliefs, norms, institutional culture, etc. Hence, people may not share the same cultural values as those from another country. Fan Y. (2006) also argues that a nation generally refers to a large group of people of the same race and language, while a country means an area of land occupied by a nation.

The notion of nation branding is fairly new, and one might wonder what it actually means. Anholt (2007:1) define nation branding "as the process of designing, planning and communicating the name and the identity, in order to build or manage the reputation (of a country)."Dinnie (2007:5) defined nation branding as "the unique, multidimensional blend of elements that provide the nation with culturally grounded differentiation and relevance for all of its target audiences."According to Dinnie (2009), it represents a mixture of multiple aspects of a nation that includes the interests of the national brand target audiences, such as the nation's distinctive political, economic, social, and cultural resources.

\section{Nation's Identity, Image, and Reputation}

National image branding describes the ways in which a whole country differentiates, symbolizes, and communicates itself to all of its audiences, which often relates to building and managing a nation's brand identity, image, and reputation. It is widely accepted that brand identity is how the brand is intended to be perceived and brand image is the perception of a brand in the minds of people. As Dinnie (2008) states, the core concepts of brand identity and brand image are eminently transferable from the context of products, services, or corporations to the context of national image branding.

As shown in research done by Schwalbach (2001), the reputation of a nation becomes an umbrella concept for the internal identity and a transmitted image of an entity (see Figure 1). The observed reputation serves as feedback to create a desired image and reflects in the identity, which is the nation's concept of itself. According to Chun (2005), identity, the desired identity, and image are three key elements of a corporate (brand/company) reputation. Gap analysis evaluate to what degree an entity manages to be accurately represented in the public eye as all three key elements interact with one and another(Chun, 2005), as shown in Figure 2.

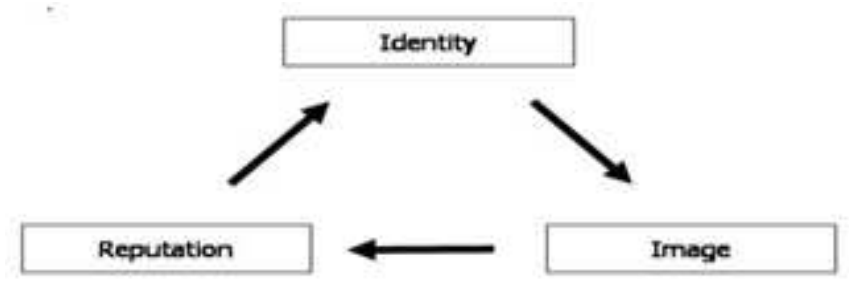

Figure 1: Interdependence of Reputation, Image and Identity

Source: extracted from Schwalbach (2001:3)http://www2.wiwi.hu-berlin.de/institute/im/publikdl/2001-4.pdf 


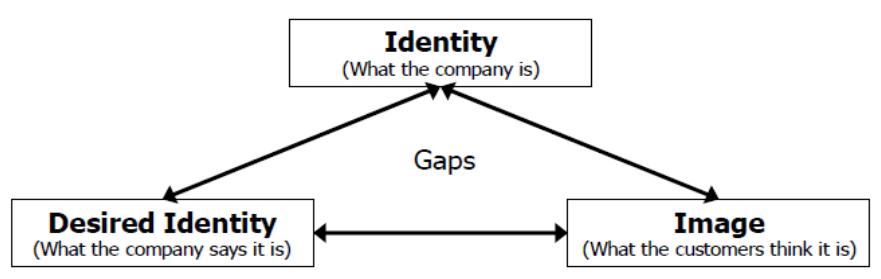

Figure 2: Elements of Corporate Reputation

Source: Extracted from Chun (2005:97) corporate reputation: Meaning and measurement

By looking at these two models above, it shows that a nation's identity and a nation's image are important; they can build a nation's reputation, which is inherited from one's umbrella concept of a nation's identity and image as a combination of self-projection and others' cognitive and emotional responses. However, one should know that a nation's identity and image are two different concepts (Nandan, 2005). The nation's identity begins with its name, culture, government, people, etc., while the nation's image originates from the perceptions of the people within and outside of that given culture. A nation's image refers to the current perception of the country in the marketplace; a nation's identity is represented by the whole aspect of a nation, and a nation's image is the consumers' perception of that nation; however often lag behind by years or even decades.

Hence, the nation identity is what the nation projected, while on the other hand nation image is how others perceived (by other countries (people) and around the world). To acquire the national identity, it requires the nation (people) to visualize a brand vision that clearly describes the nation's goal with clear objectives and it has to be achieved within a certain set dateline. Hence, Anholt (2006) pointed out, the nation image is the image perceived by the stakeholders, the national identity represents the "intended perception" (Veloutsou, 2008: 299), a country brand managers or policy makers “would like the brand to have” (Veloutsou, 2008: 299).

Thus, both nation's image and reputation are mental constructs reflecting the perception of an entity. Nevertheless, their relevance mainly springs from the human need to simplify decisions by creating symbolic representations of meanings. The nation brand image consists of various attributes and benefits associations in consumers' mind. Those nation brand attributes are the functional and mental connections with the nation's brand, it is consumers overall assessment of a nation, it can be specific or conceptual. Nation's brand benefits on the other hand, are the rationale for the decision to use or choose. Hence, there are three types of nation brand benefits: 1) functional benefits is, what do nation do better (than others), 2) emotional benefits is, how do nation make one feel better (than others), and 3) rational benefits/support benefits is, why do I believe that given nation (more than others).

In short, one can say that perception at one point in time is called image, while the perception over time is called reputation (Balmer and Greyser, 2002). Nations brand image is the overall impression in consumers' mind that is formed from all sources of the nation. Hence, people often develop various associations, based on these associations, an image is formed about the nation on the basis of subjective perceptions of association's bundle that the consumers have about the nation.

\section{METHODS}

The research began with a qualitative approach in order to generate information about the nation's brand by conducting online interviews. Fifteen interviews were conducted; ten were held with a Chinese exchange student who is 
studying in a Taiwan university, and five interviews were conducted with American brand design experts. The interview was conducted online between 04/04/2013-06/04/2013. The online interview was unstructured, which permitted the interviewees to articulate arguments, present bare facts concerning the competitiveness of a nation, nation's brand image and reputations) strategies. In this view, the interviews can be seen as a pilot study and an opportunity to collect internal information about China's national brand. After the information was collected, the author then used the information to create an online survey questionnaire for the participants to complete by means of social media (Facebook and Twitter) online between 09/20/2013-01/13/2014.

The experiment was examined on how image and reputation of Chinese (China) people different between 215 participants (116 West and 99 eastern), by way of mean score and standard deviation used a five-point bipolar Likert scales (agree totally $=1$, agree $=2$, neither $=3$, agree partially $=4$, and not agree $=5$ ), with multivariate analysis of variance (MANOVA) and analysis of variance (ANOVA) using SPSS 18.0.

\section{RESULTS AND DISCUSSIONS}

\section{Chinese Governments and Its People}

On image and reputation of Chinese government and its people, the author divides these parts into two sections; image and reputation of Chinese (China) people and image and reputation of Chinese (China) governments. The experiment was examined on how image and reputation of Chinese (China) people different between 215 participants (116 West and 99 eastern), by way of mean score and standard deviation used a five-point bipolar Likert scales (agree totally=1, agree $=2$, neither $=3$, agree partially $=4$, and not agree $=5$ ), with multivariate analysis of variance (MANOVA) and analysis of variance (ANOVA) using SPSS 18.0.

A one-way Multivariate analysis of variance (MANOVA) was first conducted to determine the effect of western and eastern on the eight dependent variables, trustworthy, dependable, intelligent, cheap, polite, selfish, respect of other, and hard-working. The results of 215 participants (116 West and 99 eastern) showed, image and reputation of Chinese (China) people overall, there were highly significant differences between the western and eastern on the dependent measures of Wilks's $\left(=.867 F(8,204)=3.905, p<.001\right.$. The multivariate $\eta^{2}$ based on Wilks's (was. 133, (see Table 1).

Then analysis of variance (ANOVA) on each dependent variable was conducted as follow-up tests to the MANOVA. The results showed there is some significant difference between western and eastern, it breakdown as follows; on trustworthy between western and eastern there is no significant difference, $F(1,211)=3.578, p>.05, \eta^{2}=.017$, on dependable between western and eastern there is no significant difference, $F(1,211)=.039, p>.05$, $\eta^{2}=.000$, on intelligent between western and eastern there is no significant difference, $F(1,211)=.007, p>.05, \eta^{2}=.000$, on cheap between western and eastern there are highly significant difference, $F(1,211)=5.899, p<.05, \eta^{2}=.027$, on polite between western and eastern there are highly significant difference, $F(1,211)=11.055, p<.01, \eta^{2}=.050$, on selfish between western and eastern there are highly significant difference, $F(1,211)=3.913, p<.05, \eta^{2}=.018$, on respect of other between western and eastern there is no significant difference, $F(1,211)=.000, p>.05, \eta^{2}=.000$, on hard-working between western and eastern there is no significant difference, $F(1,211)=.158, p>.05, \eta^{2}=.001($ see Table 1$)$. 
Table 1: Images and Reputation of Chinese (China) People between Western and Eastern (Mean Score and Standard Deviation)

\begin{tabular}{|c|c|c|c|c|c|c|}
\hline & \multicolumn{2}{|c|}{ Western } & \multicolumn{2}{|c|}{ Eastern } & \multicolumn{2}{|c|}{ Different } \\
\hline & Mean & Std. D & Mean & Std. D & $\mathbf{F}$ & $\mathbf{P}$ \\
\hline Trustworthy & 3.129 & .880 & 2.889 & .807 & 3.578 & .060 \\
\hline Dependable & 3.853 & .688 & 3.798 & .845 & .039 & .844 \\
\hline Intelligent & 3.526 & .678 & 3.515 & .861 & .007 & .931 \\
\hline Cheap & 1.724 & .568 & 1.545 & .500 & 5.899 & $.016 *$ \\
\hline Polite & 2.017 & .672 & 1.697 & .749 & 11.055 & $.001 * *$ \\
\hline Selfish & 2.819 & 1.076 & 2.566 & .859 & 3.913 & $.049 *$ \\
\hline Respect other & 2.319 & .705 & 2.313 & .737 & 1.476 & .226 \\
\hline Hard-Working & 1.810 & .617 & 1.748 & .628 & .158 & .691 \\
\hline Total & 2.650 & .277 & 2.509 & .326 & 10.292 & $.002 * *$ \\
\hline
\end{tabular}

The results of mean score and standard deviation on image and reputation of Chinese (China) people showed, on trustworthy when compare between western $(\mathrm{M}=3.129, \mathrm{SD}=.880)$ and eastern $(\mathrm{M}=2.889, \mathrm{SD}=.807)$ it showed no significant difference $(\mathrm{F}=3.578, \mathrm{P}<.060)$ between the two, on dependable between western $(\mathrm{M}=3.853, \mathrm{SD}=.688)$ and eastern $(\mathrm{M}=3.798, \mathrm{SD}=.845)$ it showed no significant difference $(\mathrm{F}=.039, \mathrm{P}<.844)$ between the two, on intelligent between western $(\mathrm{M}=3.526, \mathrm{SD}=.678)$ and eastern $(\mathrm{M}=3.515, \mathrm{SD}=.861)$ it showed no significant difference $(\mathrm{F}=.007, \mathrm{P}<.931)$ between the two, on cheap between western $(\mathrm{M}=1.724, \mathrm{SD}=.568)$ and eastern $(\mathrm{M}=1.545, \mathrm{SD}=.500)$ it showed highly significant difference $(\mathrm{F}=5.899, \mathrm{P}<.016)$ between the two, on polite between western $(\mathrm{M}=2.017, \mathrm{SD}=.672)$ and eastern $(\mathrm{M}=1.697$, $\mathrm{SD}=.749)$ it showed highly significant difference $(\mathrm{F}=11.055, \mathrm{P}<.001)$ between the two, on selfish between western $(\mathrm{M}=2.819, \mathrm{SD}=1.076)$ and eastern $(\mathrm{M}=2.566, \mathrm{SD}=.859)$ it showed highly significant difference $(\mathrm{F}=3.913, \mathrm{P}<.049)$ between the two, on respect of other between western( $\mathrm{M}=2.319, \mathrm{SD}=.705)$ and eastern $(\mathrm{M}=2.313, \mathrm{SD}=.737)$ it showed no significant difference $(\mathrm{F}=.1 .476, \mathrm{P}<.226)$ between the two, on hard-working between western $(\mathrm{M}=1.810, \mathrm{SD}=.617)$ and eastern $(\mathrm{M}=1.748, \mathrm{SD}=.628)$ it showed no significant difference $(\mathrm{F}=.158, \mathrm{P}<.691)$ between the two, and when compare the overall of 8 element on how image and reputation of Chinese (China) people are, the results showed western(M=2.650, $\mathrm{SD}=.277)$ and eastern $(\mathrm{M}=2.509, \mathrm{SD}=.326)$ had highly significant difference $(\mathrm{F}=10.292, \mathrm{P}<.002)$ between the two, see Figure 4 and Table 1.

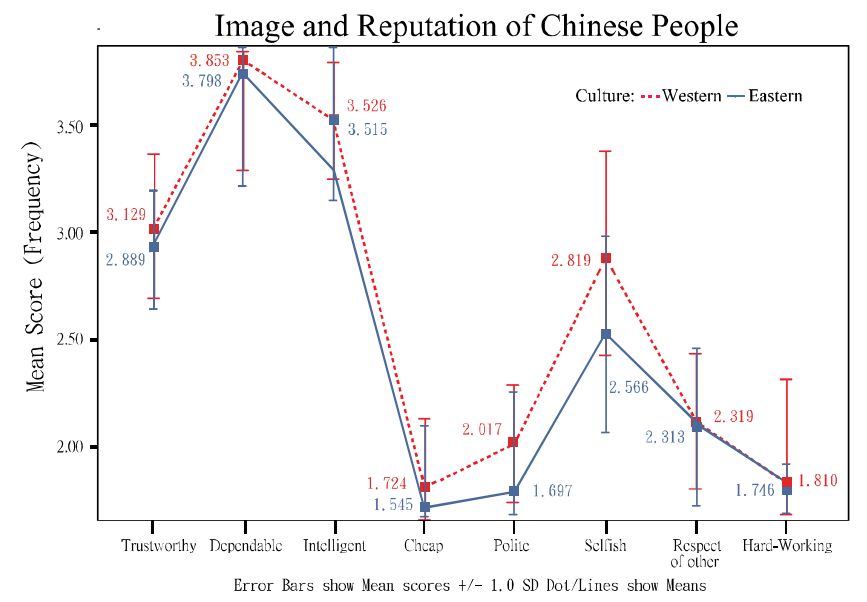

Figure 3: Images and Reputation of Chinese (China) People between Western and Eastern

Hypotheses 1.1 Images and Reputation of Chinese (China) People 
H1.1: There is a significant difference between western and eastern on the overall how Chinese people are, the test result $(\mathrm{F}=10.292, \mathrm{P}=.002)$ was accepted.

H1.1a: There is a significant difference between western and eastern on Chinese people are trustworthy, the test result $(\mathrm{F}=3.578, \mathrm{P}=.060)$ was rejected.

H1.1b: There is a significant difference between western and eastern on Chinese people are dependable, the test result $(\mathrm{F}=.039, \mathrm{P}=.844)$ was rejected.

H1.1c: There is a significant difference between western and eastern on Chinese people are intelligent, the test result $(\mathrm{F}=.007, \mathrm{P}=.931)$ was rejected.

H1.1d: There is a significant difference between western and eastern on Chinese people are cheap, the test result $(\mathrm{F}=5.899, \mathrm{P}=.016)$ was accepted.

H1.1e: There is a significant difference between western and eastern on Chinese people are polite, the test result $(\mathrm{F}=11.055, \mathrm{P}=.001)$ was accepted.

H1.1f: There is a significant difference between western and eastern on Chinese people are selfish, the test result $(\mathrm{F}=3.913, \mathrm{P}=.049)$ was accepted.

H1.1g: There is a significant difference between western and eastern on Chinese people are respect of another, the test result $(\mathrm{F}=.000, \mathrm{P}=.992)$ was rejected.

H1.1h: There is a significant difference between western and eastern on Chinese people are hardworking, the test result $(\mathrm{F}=.158, \mathrm{P}=.691)$ was rejected, (See Table 1$)$.

Next, the research examines on how image and reputation of Chinese (China) governments differentiate between 215 participants (116 West and 99 eastern), by way of mean score and standard deviation used a five-point bipolar Likert scales (agree totally=1, agree $=2$, neither=3, agree partially=4, and not agree=5), with multivariate analysis of variance (MANOVA) and analysis of variance (ANOVA) using SPSS 18.0.

A one-way Multivariate analysis of variance (MANOVA) was first conducted to determine the effect of western and eastern on the eight dependent variables, trustworthy, dependable, intelligent, sinister, unpredictable, powerful, good Legal System, and good political policy. The results of 215 participants (116 western and 99 eastern) showed, image and reputation of Chinese (China) governments overall, there were highly significant differences between he western and eastern on the dependent measures of Wilks's $\Lambda=.501 F(8,204)=25.433, p<.001$. The multivariate $\eta^{2}$ based on Wilks's (was.499, (see Table 2).

Then, analysis of variance (ANOVA) on each dependent variable was conducted as follow-up tests to the MANOVA. However, when we looked between western and eastern the results showed there is some significant difference, it breakdown as follows; trustworthy, between western and eastern there are highly significant difference, $F(1,211)=14.825$, $p<.001, \eta^{2}=.066$, dependable between western and eastern there is no significant difference, $F(1,211)=.259, p>05, \eta^{2}=.001$, intelligent between western and eastern there is no significant difference, $F(1,211)=.068, p>.05, \eta^{2}=.000$, sinister between western and eastern are highly significant difference, $F(1,211)=10.491, p<.01, \eta^{2}=.047$, unpredictable between western and eastern there are highly significant difference, $F(1,211)=5.188, p<.05, \eta^{2}=.024$, powerful between western and eastern 
there are highly significant difference, $F(1,211)=21.467, p<.001, \eta^{2}=.092$, good Legal System between western and eastern there are highly significant difference, $F(1,211)=69.401, p<.001, \eta^{2}=.248$, good political policy between western and eastern there are highly significant difference, $F(1,211)=82.968, p<.001, \eta^{2}=.282$ (see Table 2 ).

The results of mean score and standard deviation on image and reputation of Chinese (China) governments showed, on trustworthy when compare between western $(\mathrm{M}=4.569, \mathrm{SD}=.578)$ and eastern $(\mathrm{M}=4.242, \mathrm{SD}=.701)$ it showed highly significant difference $(\mathrm{F}=14.825, \mathrm{P}<.000)$ between the two, on dependable between western $(\mathrm{M}=4.181, \mathrm{SD}=.840)$ and eastern $(\mathrm{M}=4.202, \mathrm{SD}=.473)$ it showed no significant difference $(\mathrm{F}=.259, \mathrm{P}<.612)$ between the two, on intelligent between western( $\mathrm{M}=2.620, \mathrm{SD}=.910)$ and eastern $(\mathrm{M}=2.678, \mathrm{SD}=.617)$ it showed no significant difference ( $\mathrm{F}=.068$, $\mathrm{P}<.794)$ between the two, on sinister between western $(\mathrm{M}=1.819, \mathrm{SD}=.729)$ and eastern $(\mathrm{M}=1.546, \mathrm{SD}=.500)$ it showed highly significant difference $(\mathrm{F}=10.491, \mathrm{P}<.001)$ between the two, on unpredictable between western $(\mathrm{M}=1.629, \mathrm{SD}=.626)$ and eastern $(\mathrm{M}=1.444, \mathrm{SD}=.519)$ it showed no significant difference $(\mathrm{F}=5.188, \mathrm{P}<.024)$ between the two, on powerful between western $(\mathrm{M}=1.707, \mathrm{SD}=.632)$ and eastern $(\mathrm{M}=2.0403, \mathrm{SD}=.533)$ it showed highly significant difference $(\mathrm{F}=21.467, \mathrm{P}<.000)$ between the two, on good legal system between western $(\mathrm{M}=4.793, \mathrm{SD}=.519)$ and eastern $(\mathrm{M}=4.141$, $\mathrm{SD}=.639)$ it showed highly significant difference $(\mathrm{F}=69.401, \mathrm{P}<.000)$ between the two, on good political policy between western $(\mathrm{M}=4.655, \mathrm{SD}=.477)$ and eastern $(\mathrm{M}=3.939, \mathrm{SD}=.667)$ it showed highly significant difference $(\mathrm{F}=82.968, \mathrm{P}<.000)$ between the two, and when compare the overall of 8 element on image and reputation of Chinese (China) governments are, the results showed western( $\mathrm{M}=3.247, \mathrm{SD}=.173)$ and eastern $(\mathrm{M}=3.030, \mathrm{SD}=.204)$ had highly significant difference ( $F=79.694, \mathrm{P}<.006)$ between the two, see Figure 4 and Table 2.

Table 2: Images and Reputation of Chinese (China) Governments between Western and Eastern (Mean Score and Standard Deviation)

\begin{tabular}{|l|c|c|c|c|c|c|}
\hline \multirow{2}{*}{} & \multicolumn{2}{|c|}{ Western } & \multicolumn{2}{c|}{ Eastern } & \multicolumn{2}{c|}{ Different } \\
\cline { 2 - 7 } & Mean & Std. D & Mean & Std. D & F & P \\
\hline Trustworthy & $\mathbf{4 . 5 6 9}$ & .578 & 4.242 & .701 & $\mathbf{1 4 . 8 2 5}$ & $.000 * * *$ \\
\hline Dependable & $\mathbf{4 . 1 8 1}$ & .840 & 4.202 & .473 & .259 & .612 \\
\hline Intelligent & $\mathbf{2 . 6 2 0}$ & .910 & 2.687 & .617 & .068 & .794 \\
\hline Sinister & $\mathbf{1 . 8 1 9}$ & .729 & 1.546 & .500 & $\mathbf{1 0 . 4 9 1}$ & $.001 * *$ \\
\hline Unpredictable & $\mathbf{1 . 6 2 9}$ & .626 & 1.444 & .519 & $\mathbf{5 . 1 8 8}$ & .024 \\
\hline Powerful & $\mathbf{1 . 7 0 7}$ & .632 & $\mathbf{2 . 0 4 0}$ & .533 & $\mathbf{2 1 . 4 6 7}$ & $.000 * * *$ \\
\hline Good Legal System & $\mathbf{4 . 7 9 3}$ & .519 & 4.141 & .639 & $\mathbf{6 9 . 4 0 1}$ & $.000 * * *$ \\
\hline Good Political Policy & $\mathbf{4 . 6 5 5}$ & .477 & $\mathbf{3 . 9 3 9}$ & .667 & $\mathbf{8 2 . 9 6 8}$ & $.000 * * *$ \\
\hline \multicolumn{1}{|c|}{ Total } & 3.247 & .173 & 3.030 & .204 & $\mathbf{7 9 . 6 9 4}$ & $.006 * *$ \\
\hline
\end{tabular}

Not Agree =5; Agree Partially=4; Somewhat=3; Agree=2; Agree Totally=1

$* * * \mathrm{p}<.001, * * \mathrm{p}<.01, * \mathrm{p}<.05$ 


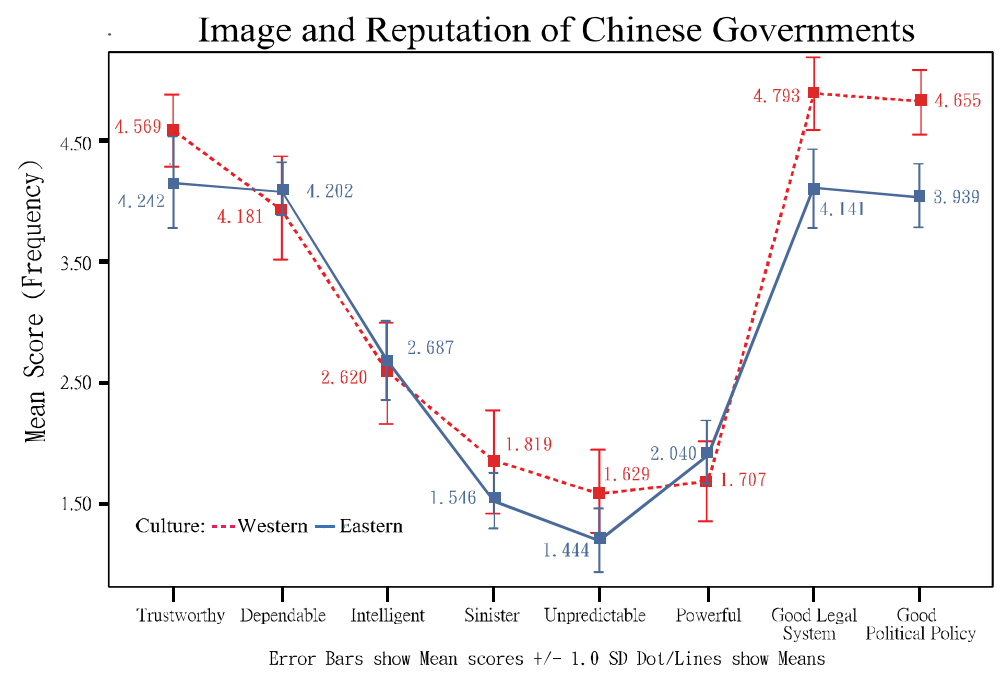

Figure 4: Images and Reputation of Chinese (China) People and Government between Western and Eastern

Hypotheses 1.2 Images and Reputation of Chinese (China) Government

H1.2: There is a significant difference between western and eastern on the overall how Chinese government are, the test result $(\mathrm{F}=79.694, \mathrm{P}=.006)$ was accepted.

H1.2a: There is a significant difference between western and eastern on Chinese government are trustworthy, the test result $(\mathrm{F}=14.825, \mathrm{P}=.000)$ was accepted.

H1.2b: There is significant difference between western and eastern on Chinese government are dependable, the test result $(\mathrm{F}=.259, \mathrm{P}=.612)$ was rejected.

H1.2c: There is a significant difference between western and eastern on Chinese government are intelligent, the test result $(\mathrm{F}=.068, \mathrm{P}=.794)$ was rejected.

H1.2d: There is a significant difference between western and eastern on Chinese government are sinister, the test result $(\mathrm{F}=10.491, \mathrm{P}=.001)$ was accepted.

H1.2e: There is a significant difference between western and eastern on Chinese government are unpredictable, the test result $(\mathrm{F}=5.188, \mathrm{P}=.024)$ was rejected.

H1.2f: There is a significant difference between western and eastern on Chinese government had world power (powerful), the test result $(\mathrm{F}=21.467, \mathrm{P}=.000)$ was accepted.

H1.2g: There is a significant difference between western and eastern on Chinese government had good legal system, the test result $(\mathrm{F}=69.401, \mathrm{P}=.000)$ was accepted.

H1.1h: There is a significant difference between western and eastern on Chinese government are had good political policy, the test result $(\mathrm{F}=82.968, \mathrm{P}=.006)$ was accepted, (See Table 2).

\section{CONCLUSIONS}

Sustainable competitiveness of a nation activities is designed to reach a great number of people regardless of social status; they are also intended to invite involvement in such things as traveling, purchasing cultural products, 
experiencing art, and so on. Competitiveness of a nation does not have magical powers and often is a long process to reduce the gap between people's wrong perceptions and reality. It often reflects all necessary areas a country wants to highlight in order to create positive images and positioning. Competitiveness of a nation is not just a loose marketing activity, but something holistic that influence the whole nation's identity (projected by the country), image, and reputation (perceived by the rest of the world). However, the nation should understand competitiveness of a national strategy cannot be valid or sustainable unless all stakeholders are involved and agree on the principles of the nation.

Therefore, nation' will claim a brand position based on their actions. Just like any individuals' personalities are determined based on how they are being viewed over time by others, the same is true of nations 'and its products. To claim a positive nation brand's position, it requires ongoing efforts to convey a consistent image to target audiences through all nation 'activities, from the attributes of the product itself to the nations' service to the nation 'people and through promotional activities. It is consistency over time, reflected through actual performance that will help a nation effectively claim a brand's position.

National positioning also involves identifying ways in which your nation's offerings differ from competitors' offerings. Based on the target market areas, the nation will identify competitors in those markets, learn as much about those competitors as possible and determine how the nation might claim a different position based on its own marketing attributes. Once the desired position has been established, the nation will work to establish and strengthen a nation's brand identity designed to claim that position within the market place. Having a positive image can make a world of difference to a country, city or region, just as it does for companies and their products. A strong national brand helps to attract investment, talent, consumers and tourists, and enhances the country's cultural and political influence.

\section{REFERENCES}

1. Anholt, S. (2005). Anholt Nation Brands Index: How Does the World See America? Journal of Advertising Research,45(3), 296-304.

2. Anholt, S. (2006). Public Diplomacy and Place Branding: Where's the Link? Place Branding, 2 (4), 271-275.

3. Anholt, S. (2007). Competitive Identity: The New Brand Management for Nations, Cities and Region. Palgrave Macmillan, New York.

4. Anholt, S. (2008). Nation Branding in Asia, Place Branding and Public Diplomacy, 4 (4), 265-269.

5. Balmer, J. M. T., \& Greyser, S. A. (2002). Managing the Multiple Identities of the Corporation. California Management Review, 44(3), 72-86.

6. Caldwell, N. \& Freire, J. R. (2004). The differences between branding a country, a region and a city: applying the brand box model. Journal of Brand Management, 12(1), 50-61

7. Chun, R. (2005). Corporate reputation: Meaning and measurement. International Journal of Management Reviews, 7(2), 91 109.

8. Dinnie, K. (2007). Nation Branding: Concepts, Issues, Practice. Chicago: Butterworth-Heinemann.

9. Dinnie, K. (2008). Nation Branding: Concepts, Issues, Practice, Elsevier Ltd., Oxford.

10. Dinnie, K. (2009). Nation branding: Concepts, issues, practice, New York, NY: Elsevier Ltd.

11. Fan Y. (2006), Branding The Nation: What Is Being Branded? Journal of Vocation Marketing, 12(1), 5-14. 
12. Freire, J. R. (2005). Geo-branding, are we talking nonsense? A theoretical reflection on brands applied to places. Place Branding, 1(4), 347-62.

13. Frost, R. (2004). Mapping the country's future. http://www.brandchannel.com/features_effect.asp?pf_id=206/retrieved 04/19/2008].

14. Gold, E. R. (2006). Intellectual architecture as place brand. Place Branding, 2(3), 220-228.

15. Kapferer, J. (1997), Strategic Brand Management. Creating and Sustaining Brand Equity Long Term. London: Kogan Page Ltd.

16. Nandan, S. (2005). An exploration of the brand identity-brand image linkage: A communication perspective. Brand Management, 12(4), 264-278.

17. O'Shaughnessy, J. \& O'Shaughnessy, N. J. (2000). Treating the nation as a brand: some neglected issues. Journal of Macro marketing, 20(1), 56-64.

18. Papadopoulos, N. (2004). Place branding: evolution, meaning and implications. Place Branding, 1(1), 36-49.

19. Schwalbach, J. (2001). Unternehmens reputation als Erfolgsfaktor. Berlin (Institut für Management, Humboldt-Universität), http://www2.wiwi.hu-berlin.de/institute/im/publikdl/2001-4.pdf [retrieved 09/23/2006].

20. Veloutsou, C. (2008). Branding: A Constantly Developing Concept. Journal of Brand Management, 15 (5), $299-300$. 
